\title{
Description of atypical pattern in twins with presumed congenital Zika and without microcephaly - Case Report
}

\author{
OOpen acess \\ Ana Carolina Peixoto e Lucena Fontes ${ }^{1,2}$, Italla Maria Pinheiro \\ Bezerra $^{1,3}$, Luiz Carlos de Abreu ${ }^{1,3}$
}

\begin{abstract}
${ }^{1}$ Laboratório de Delineamento de Estudos e Escrita Científica. Centro Universitário FMABC.
\end{abstract}

\section{${ }^{2}$ Universidade Estadual de Pernambuco. Campus de Serra talhada, PE, Brasil.}

${ }^{3}$ Escola Superior de Ciências da Santa Casa de Misericórdia de Vitória (EMESCAM)

\section{Corresponding author:} anacarol.lucena@gmail.com

Manuscript received: April 2018 Manuscript accepted: October 2018 Version of record online: November 2018

\begin{abstract}
Introduction: Zika virus (ZIKV) infection was a public health emergency of Brazilian national interest until May 2017, due to the sudden increase in newborns with microcephaly and other neurological alterations during the epidemic started in Brazil in November 2015. The manifestations of Intrauterine infections by ZIKV are more severe when they occur in the first and second trimesters of gestation, especially in the first trimester. In this situation, early diagnosis of visual problems is essential for patients to progress in the neurological and motor fields, and there are complications such as refractive errors (myopia, astigmatism and hyperopia), strabismus and hypoactomy. The absence of microcephaly in infants exposed to the zika virus is not indicative of changes in ophthalmology, and it is essential that the ophthalmologist perform the investigations that are relevant to the clinical case. Any and all eye lesions and their consequences are serious. The earlier the diagnosis, the sooner the child can undergo an intervention to enable vision.
\end{abstract}

Objective: To analyze atypical pattern in twins with presumed congenital zika and without microcephaly.

Method: This is a case report, developed in the city of Serra Talhada, in the state of Pernambuco, Northeast Brazil.

Report: Case of twins whose mother was exposed to zika virus in the second trimester of gestation (eleventh week). The children were born prematurely and without microcephaly. One of the twins had hydrocephalus requiring surgery. The same child was taken for ophthalmologic examination because of convergent strabismus; and hypocortical optic nerve and chorioretinal scar were found in the macular region in both eyes similar to the lesions described by zika virus. A similar scenario, but with less visual impairment was identified in the second twin. Skull tomography demonstrated bilateral calcification foci in the cerebral hemispheres.

Conclusion: There was presence of convergent deviation and nystagmus to lateroversions. In the funduscopy, the optic nerve was pale and with cicatricial chorioretinal lesion with well delimited edges in the macular area of both eyes.

Keywords: pregnancy, Zika virus, ophthalmology, vision disorders.

Suggested citation: Fontes ACPL, Bezerra IMP, Abreu LC. Description of atypical pattern in twins with presumed congenital Zika and without microcephaly - Case Report. Journal of Human Growth and Development. 2018; 28(3): 348-355. DOI: http://dx.doi.org/10.7322/jhgd.152196 


\section{INTRODUCTION}

The Zika virus infection (ZIKV) was a public health emergency of Brazilian national interest until May 2017, due to the sudden increase in newborns with microcephaly and other neurological changes during the epidemic that started in Brazil in November 2015. The manifestations of intrauterine infection by ZIKV are more severe when they occur in the first and second trimesters of gestation, especially in the first trimester.

The first case of ZIKV infection occurred in 1953 in Nigeria ${ }^{1}$. After this first report, the virus circulated silently for more than 50 years in Africa and Asia, and few cases were described in isolation and without evidence of serious complications ${ }^{2-5}$.

It is known that the disease is transmitted by the Aedes mosquito, whose most important species in the transmission of recent outbreaks are Aedes aegypti and to a lesser extent Aedes albopictus ${ }^{4-7}$. In Brazil, Aedes aegypti is endemic and is also a vector of other arboviruses such as dengue and chikungunya ${ }^{4,8,9}$, which have clinical presentations similar to Zika, whose classic symptomatology is mild and self-limiting, usually with a maculopapular rash, low fever, arthritis or arthralgia, conjunctivitis, myalgia, headache and edema, being asymptomatic in most cases ${ }^{6,10,11}$. Other forms of ZIKV transmission such as sexual ${ }^{12-15}$, blood transfusion ${ }^{16}$ and perinatal ${ }^{17}$ have also been described.

Initially documented in April $2015^{18,19}$, the outbreak of Zika in Brazil reached pandemic proportions ${ }^{20,21}$, spreading rapidly across the continent. It is postulated that this arbovirus was brought from the Pacific Islands during sports events in Brazil in 2014 18,22 . An increase in the notification of cases of children born with microcephaly in the Northeast region ${ }^{23}$ concomitant with the Zika outbreak caused a possible causal association between microcephaly and ZIKV infection during pregnancy ${ }^{24}$, however, such a finding by the World Health Organization and by CDC (US Centers for Disease Control and Prevention) only occurred in April $2016^{25,26}$. In compliance with the public health risk framework, in 2016 in Brazil, health surveillance measures were adopted based on laws published after the outbreak, in order to control dissemination of the transmitting mosquito and also to support the families of children with microcephaly ${ }^{27}$.

The confirmation of vertical transmission of ZIKV joined forces in the characterization of a new entity: Congenital Zika syndrome. In this syndrome, ocular abnormalities, arthrogryposis and auditory deficits, as well as microcephaly and neurological abnormalities have been described ${ }^{8,28-30}$. However, there have been few reports of changes in newborns whose mothers were exposed to ZIKV during pregnancy and who did not present microcephaly at birth ${ }^{31-35}$, since it has been the criterion used for diagnosis and investigation of congenital Zika in most studies.

In addition, the early diagnosis of visual problems is essential for patients to progress in the neurological and motor fields, with complications such as refractive errors (myopia, astigmatism and hyperopia), strabismus and hypoactomy. The absence of microcephaly in infants exposed to Zika virus is not indicative of changes in ophthalmology, and it is essential for the ophthalmologist to carry out the investigations pertinent to the clinical case. Any and all eye lesions and their attachments are serious. The earlier the diagnosis, the earlier the child can undergo an intervention to enable vision

Thus, this report describes the case of a twin pregnancy in which the mother was infected by ZIKV during pregnancy and the children were born with ophthalmological and neurological alterations, but without microcephaly.

\section{CASE REPORT}

Twenty-one dizygotic twins, a girl and a boy, were born in Serra Talhada, a city in the interior of the state of Pernambuco, Brazil, in June 2016. The 31-year-old female presented a rash with pruritus, low fever and edema in the fourth month of gestation, but was not subjected to further investigation at the time. She made prenatal care without any other changes in the five appointments registered on the pregnant woman's card. The patient underwent four obstetric ultrasonographies (USG) with no evidence of abnormalities as well as laboratory tests performed routinely in prenatal care (rubella, toxoplasmosis, VDRL and HIV). The mother denied using illicit drugs, alcohol and smoking. Delivery occurred vaginally at the 34th week of gestation, without complications. Data on the birth of children are given in table 1 .

Table 1: Characterization of infants exposed to Zika virus in the city of Serra Talhada, PE, Northeast Brazil, 2018.

\begin{tabular}{lcc}
\hline & Twin 1 & Twin 2 \\
\hline HC (cm) & 28 & 29 \\
TP (cm) & 27 & 27 \\
AP (cm) & 25 & 25 \\
Weight (g) & 1640 & 1675 \\
Height (cm) & 40 & 41 \\
Apgar 1' & 05 & 08 \\
Apgar 5' & 07 & 09 \\
\hline
\end{tabular}

(HC: head circumference, TP: thoracic perimeter, AP: abdominal perimeter, 1': 1 minute, 5': 5 minutes)

The newborns were referred to the city of Recife for supportive therapy and weight gain in a neonatal intensive care unit.

\section{Twin 1 (girl)}

She was submitted, at three months of age, to endoscopic third ventriculostomy surgery with placement of ventriculoperitoneal shunt. Computerized axial tomography of the skull showed centers of calcification in the cerebral hemispheres bilaterally, more evident in the projection of the cauda-thalamic grooves and ventriculomegaly (Figure 1). 


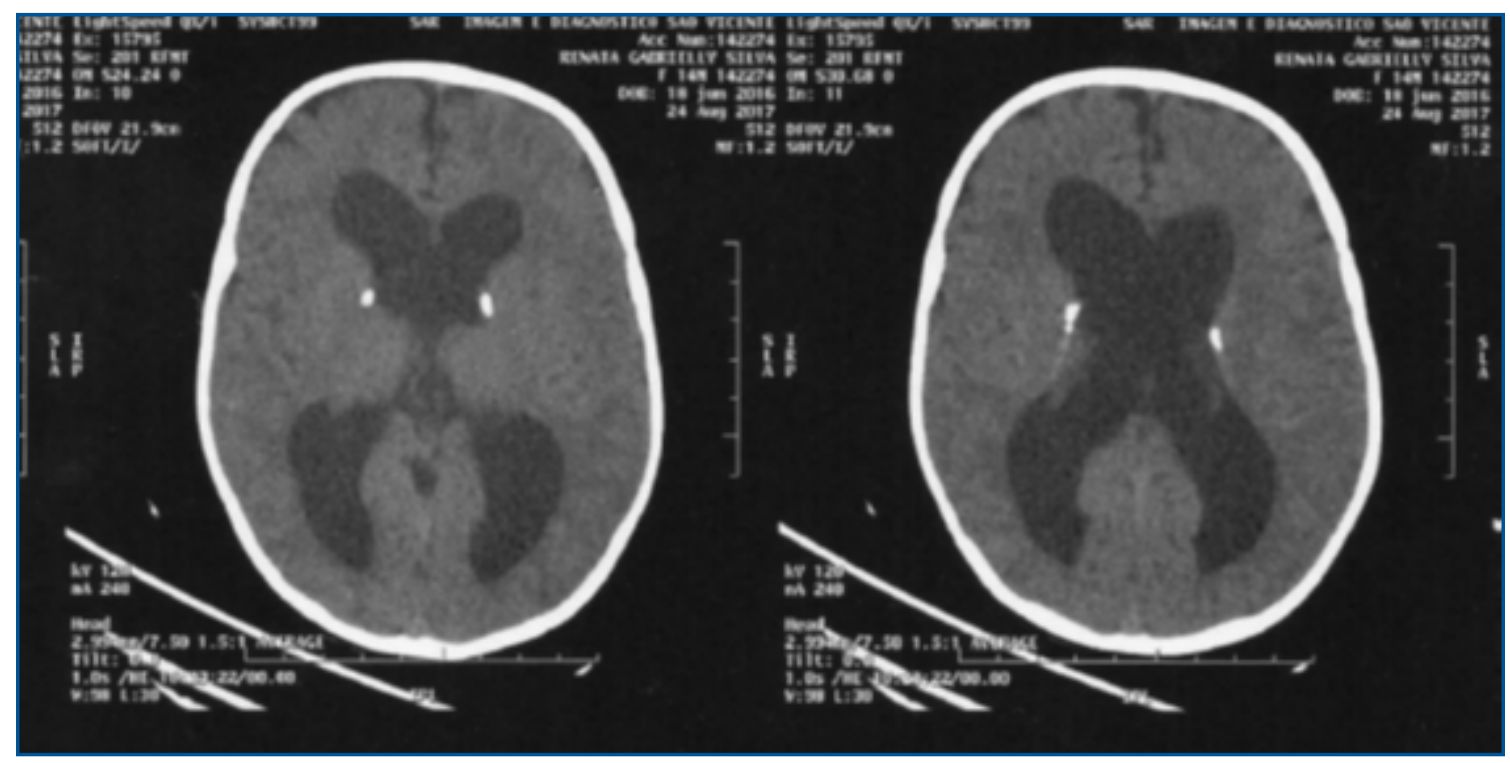

Figure 1: Axial computed tomography of the skull (Twin 1)

Twin 1 started suffering seizures. EEG examination (Figure 2), showed disorganization of the base rate with focal epileptiform activity, often in bilateral parietal projections occurring synchronously and independently; and having started phenobarbital for seizure control.

The child was brought by the mother at seven months for ophthalmological consultation under complaints of strabismus. Upon examination, convergent deviation and nystagmus were observed for lateroversions. In the fundoplication, the optic nerve (NO) was pale and cicatricial chorioretinal lesion with well delimited edges in the macular area of both eyes was found, similar to lesions previously described in congenital Zika (Figure 3). Table 2 presents the data of the ophthalmologic examination. At 8 months, the neurological exam presented a head circumference of $41.5 \mathrm{~cm}$, and open anterior fontanelle with $3 \mathrm{~cm}$. She sat with support, smiled at the stimuli, followed with a vertical and horizontal gaze and chirped. The auditory evaluation was normal.

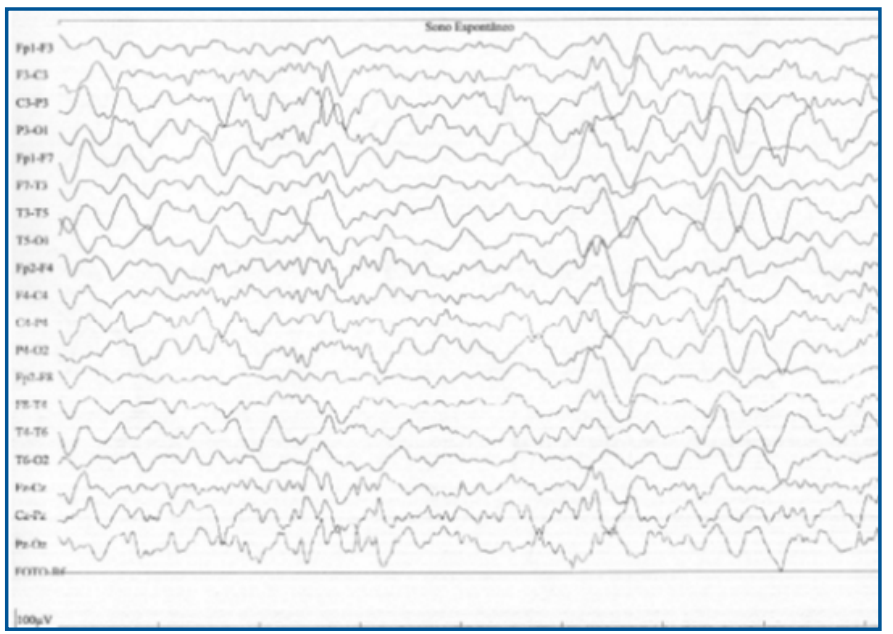

Figure 2: Electroencephalogram (Twin 1)

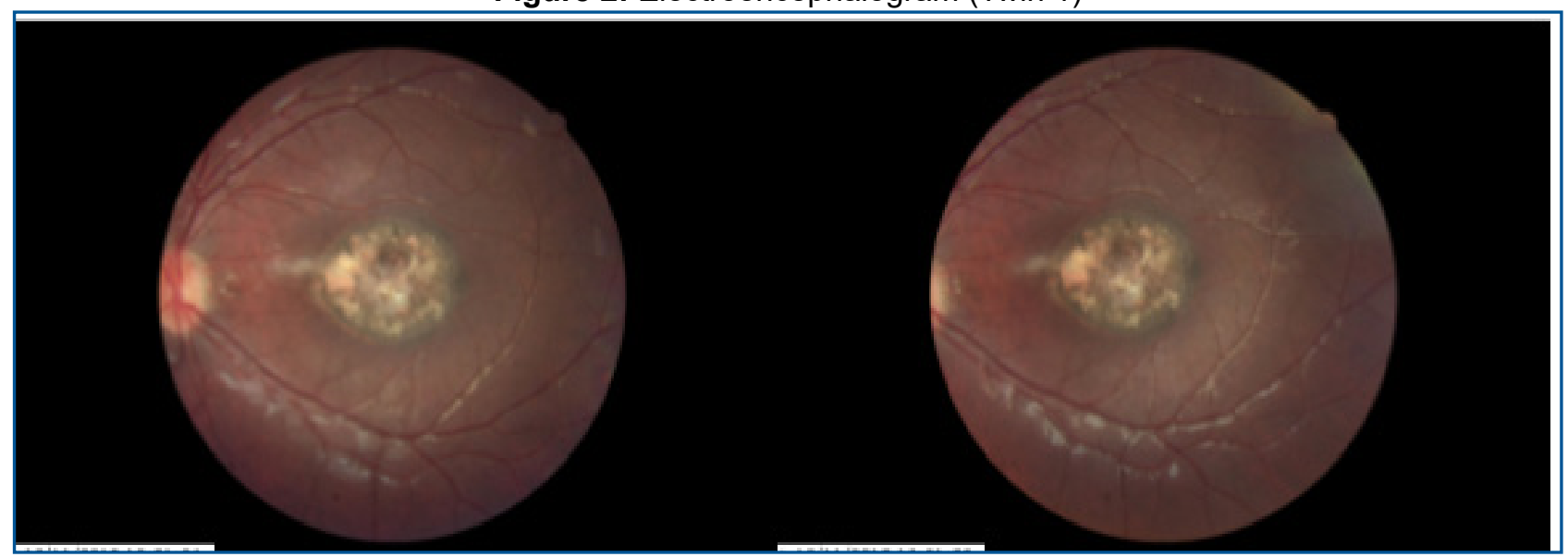

Figure 3: Fundoscopic examination (Twin 1) 
Table 2: Data from the ophthalmological evaluation of the twins, born in the city of Serra Talhada, PE, northeastern Brazil, 2018.

\begin{tabular}{lll}
\hline & Twin $\mathbf{1}$ & Twin 2 \\
\hline Visual acuity & 2.4 cy/cm (Teller $38 \mathrm{~cm})$ & $4.8 \mathrm{cy} / \mathrm{cm}$ (Teller $55 \mathrm{~cm})$ \\
Eye movements & Nystagmus & Normal \\
Strabismus & Esotropia (30 PD) & Absent \\
Ametropia & Hypermetropy & Hypermetropy \\
Biomicroscopy & Normal & Normal \\
Fundoscopy & Chorioretinal lesion & Chorioretinal lesion in \\
& in macular area and & peripheral area, normal \\
\hline
\end{tabular}

\section{Twin 2 (male)}

During the first six months, he was sent to childcare consultations without identifying phenotypic changes or delayed neuropsychomotor development. $\mathrm{He}$ underwent ophthalmologic examination at seven months after identification of fundus lesions in his sister. In funduscopy, mottled pigmentation was detected at the posterior pole and chorioretinal lesion already healed in both eyes (Figure 3). Table 2 presents data from the ophthalmological examination of both children. Neurological evaluation at eight months of age demonstrated normal neuropsychomotor development for the age. Auditory assessment was normal.

Screening tests for the most common causes of congenital infection (toxoplasmosis, cytomegalovirus, rubella, syphilis, herpes and HIV) and also dengue and chikungunya were negative for mother and children. IgG serology for Zika virus (ELISA) was positive in the mother, but negative in the infants.

\section{DISCUSSION}

Most of the current findings that direct medical care, as far as congenital Zika is concerned, are based on children with some degree of microcephaly. In this report, the possibility of individuals having visual and neurological problems is demonstrated; even in the absence of microcephaly, in an atypical setting of intrauterine exposure to Zika Virus (ZIKV). Few studies have described changes in these circumstances ${ }^{31-35}$, but so far no reports have been found on twins.

Of the patients with microcephaly and infection presumed by ZIKV, 24 to $55 \%$ will present ocular alterations ${ }^{36}$, however there is no way to estimate this appearance in children who did not develop microcephaly at birth. Zin et al. ${ }^{34}$ found ophthalmological alterations in eight $(13.1 \%)$ of the 61 newborns of pregnant women with ZIKV-positive serology and no central nervous system (CNS) abnormalities and $6.5 \%$ of those born with systemic abnormalities of the central nervous system (CNS), but without microcephaly.

Among the most common ophthalmologic findings described in association with congenital $\mathrm{Zika}^{31-40}$, the scarred chorioretinal lesion in the macula and the posterior pole mottled pigmentation were identified in the twins of this case report, which triggered the investigation of the mother's exposure to the Zika virus. Reports of pallor of the optic nerve, convergent strabismus and horizontal nystagmus were also found ${ }^{35,38}$ but the pattern of ocular findings differs from other classic congenital infections $^{34,41,42}$.

In agreement with the literature ${ }^{43}$, the involvement of the twins described here is in different degrees. Even in the absence of microcephaly, the first twin presented neurological alterations compatible with congenital Zika spectrum $^{36,44}$ ventriculomegaly, cerebral calcifications and epilepsy, but with an atypical phenotype of lower expression. Hydrocephalus and intra-cranial hypertension have also been identified in some cases as part of the clinical presentation of congenital infection by $\mathrm{ZIKV}^{45}$, and in this report there is a clinical occurrence. In addition, Oliveira-Szejnfeld et $a l .{ }^{46}$ emphasize that in cerebral ventricle obstruction, the cephalic perimeter may be normal and even increased, making it difficult to diagnose Zika Syndrome, since it is characterized by the presence of microcephaly.

The complete spectrum of changes associated with congenital Zika is not known, as the atypical phenotype of the syndrome is still being elucidated. In this context, the discussion on the damage caused by congenital infection by Zika virus and its consequences raises a number of issues, including legal ones, such as abortion, in order to better assist the families involved or possibly involved, since measures that involve the population guarantee positive return on health issues. More studies in this sense are needed to support legislation and decisions that guide such controversial issues ${ }^{47,48}$.

In addition, one of the main ways to assist in health issues, especially in cases of endemic diseases such as Zika is health promotion, especially in guiding the population to avoid measures that aid the development of the mosquito, expanding the traditional preventive model and ensuring a better quality of life for the population. Because health promotion is associated with a set of factors that constitute a humane and holistic care ${ }^{49-51}$.

Recently, a genetic study ${ }^{52}$ demonstrated that the susceptibility to ZIKV infection in gestation has a genetic origin justifying the different expressions of the syndrome in each individual. However, this does not exclude that other mechanisms are involved in vertical transmission such as placental barrier, viral load distribution and virus tropism.

The gap between birth and the first medical evaluation to raise the diagnostic hypothesis of congenital Zika demonstrates the fragility of the surveillance 
protocol $^{53}$ recommended by the Brazilian Ministry of Health, both in the failure to report cases of rash during pregnancy and in the fact of microcephaly being the starting point for research. This situation conveys a reality that does not fit with practice, where a larger universe of children has been affected and neglected, not being included in the statistics of the State.

Furthermore, considering that the majority of normal delivery NBs present (overlapping) horse sutures, it may occur that the head circumference is transiently below the cutoff parameter, it is recommended that the reference measure for microcephaly notification be performed only 24 hours after birth ${ }^{53}$. Professionals should identify children who are deficient in neurological, psychological and motor development. It should also guide the mother or caretaker about the early stimulation measures and refer them to the specialized service when necessary ${ }^{53}$.

It is essential for ophthalmological examination of the fundus of the eye to be performed in children exposed or suspected of exposure to the Zika Virus.

Thus, the study in question showed that other health problems can affect children whose mother was infected during pregnancy, evidencing the importance of quality care for individuals during the disease process. Finally, the study further adds information to the already described atypical phenotype of congenital Zika syndrome with the ophthalmologist having a relevant role in the initial diagnosis. Also, that at the ophthalmological examination, it was observed that there was presence of convergent deviation and nystagmus to lateroversions. In the funduscopy, the optic nerve was pale and with cicatricial chorioretinal lesion with well delimited edges in the macular area of both eyes.

Infant follow-up is essential for detecting potential changes in ocular development and maintaining full potential for growth and development.

\section{Author Contributions}

A.C.Lucena had full access to all the data in the study and takes responsibility for the integrity of the data and the accuracy of the data analysis.

\section{Study concept and design}

A.C.Lucena, IMP Bezerra and LC Abreu.

\section{Acquisition, analysis, or interpretation of data \\ A.C.Lucena, IMP Bezerra and LC Abreu.}

\author{
Drafting of the manuscript \\ A.C.Lucena, IMP Bezerra and LC Abreu.
}

\section{Critical revision of the manuscript for important intellectual content}

A.C.Lucena, IMP Bezerra and LC Abreu.

\section{REFERENCES}

1. MacNamara FN. Zika virus: a report on three cases of human infection during an epidemic of jaundice in Nigeria. Trans R Soc Trop Med Hyg. 1954;48(2):139-45. DOI: https://dx.doi.org/10.1016/00359203(54)90006-1

2. Fagbami AH. Zika virus infections in Nigeria: virological and seroepidemiological investigations in Oyo State. J Hyg (Lond). 1979;83(2):213-9.

3. Olson JG, Ksiazek TG, Suhandiman, Triwibowo. Zika virus, a cause of fever in Central Java, Indonesia. Trans R Soc Trop Med Hyg. 1981;75(3):389-93. DOI: https://dx.doi.org/10.1016/0035-9203(81)90100-0

4. Simpson DIH. Zika virus infection in man. Trans R Soc Trop Med Hyg.1964;58(4):335-8. DOI: https://dx.doi.org/10.1016/0035-9203(64)90200-7

5. Petersen LR, Jamieson DJ, Powers AM, Honein MA. Zika virus. N Engl J Med. 2016;374:1552-63. DOI: https://dx.doi.org/10.1056/NEJMra1602113

6. Cardoso CW, Paploski IA, Kikuti M, Rodrigues MS, Silva MM, Campos GS, et al. Outbreak of Exanthematous IIIness Associated with Zika, Chikungunya, and Dengue Viruses, Salvador, Brazil. Emerg Infect Dis. 2015;21(12):2274-6. DOI: https://dx.doi.org/10.3201/eid2112.151167

7. Centers of Disease Control and Prevention (CDC). Symptons, diagnosis \& treatment. [cited 2018 Jan 28] Available from: https://www.cdc.gov/zika/symptoms/index.html.

8. Chan JF, Choi GK, Yip CC, Cheng VC, Yuen KY. Zika fever and congenital Zika syndrome: An unexpected emerging arboviral disease. J Infect. 2016;72(5):507-24. DOI: https://dx.doi.org/10.1016/j.jinf.2016.02.011

9. Chouin-Carneiro T, Vega-Rua A, Vazeille M, Yebakima A, Girod R, Goindin D, et al. Differential Susceptibilities of Aedes aegypti and Aedes albopictus from the Americas to Zika Virus. PLoS Negl Trop Dis. 2016;10(3):e0004543. DOI: https://dx.doi.org/10.1371/journal.pntd.0004543

10. Duffy MR, Chen TH, Hancock WT, Powers AM, Kool JL, Lanciotti RS, et al. Zika virus outbreak on Yap Island, Federated States of Micronesia. N Engl J Med. 2009;360(24):2536-43.

DOI: https://dx.doi.org/10.1056/NEJMoa0805715

11. Brasil P, Pereira Jr JP, Moreira ME, Nogueira RMR, Damasceno L, Wakimoto M, et al. Zika Virus Infection in Pregnant Women in Rio de Janeiro. N Engl J Med. 2016;375(24):2321-34. DOI: https://dx.doi.org/10.1056/NEJMoa1602412 
12. Gulland A. Men and women should practise safe sex for six months to avoid Zika, says WHO. BMJ. 2016;354:i4897. DOI: https://dx.doi.org/10.1136/bmj.i4897

13. Musso D, Roche C, Robin E, Nhan T, Teissier A, Cao-Lormeau VM. Potential sexual transmission of Zika virus. Emerg Infect Dis. 2015;21(2):359-61. DOI: https://dx.doi.org/10.3201/eid2102.141363

14. Oster AM, Brooks JT, Stryker JE, Kachur RE, Mead P, Pesik NT, et al. Interim guidelines for prevention of sexual transmission of Zika virus-United States, 2016. MMWR Morb Mortal Wkly Rep. 2016;65(5):120-1. DOI: http://dx.doi.org/10.15585/mmwr.mm6505e1

15. Mansuy JM, Dutertre M, Mengelle C, Fourcade C, Marchou B, Delobel P, et al. Zika virus: high infectious viral load in semen, a new sexually transmitted pathogen? Lancet Infect Dis. 2016;16(4):405. DOI: https://dx.doi.org/10.1016/S1473-3099(16)00138-9

16. Musso D, Nhan T, Robin E, Roche C, Bierlaire D, Zisou K, et al. Potential for Zika virus transmission through blood transfusion demonstrated during an outbreak in French Polynesia, November 2013 to February 2014. Euro Surveill. 2014;19(14):20761.

17. Besnard M, Lastere S, Teissier A, Cao-Lormeau V, Musso D. Evidence of perinatal transmission of Zika virus, French Polynesia, December 2013 and February 2014. Euro Surveill. 2014;19(13):20751.

18. Zanluca C, Melo VC, Mosimann AL, Santos GI, Santos CN, Luz K. First report of autochthonous transmission of Zika virus in Brazil. Mem Inst Oswaldo Cruz. 2015;110(4):569-72. DOI: https://dx.doi.org/10.1590/0074-02760150192

19. Campos GS, Bandeira AC, Sardi SI. Zika Virus Outbreak, Bahia, Brazil. Emerg Infect Dis. 2015;21(10):1885-6. DOI: https://dx.doi.org/10.3201/eid2110.150847

20. Dick GWA, Kitchen SF, Haddow AJ. Zika virus (I). Isolations and serological specificity. Trans R Soc Trop Med Hyg. 1952;46(5):509-20. DOI: https://dx.doi.org/10.1016/0035-9203(52)90042-4

21. Darko R, Mashburn JL. Zika Virus Disease: case report and review of literature. Pediatr Emerg Care. 2016;32(10):705-9. DOI: https://dx.doi.org/10.1097/PEC.0000000000000932

22. Musso D. Zika Virus Transmission from French Polynesia to Brazil. Emerg Infect Dis. 2015;21(10):1887. DOI: https://dx.doi.org/10.3201/eid2110.151125

23. Schuler-Faccini L, Ribeiro EM, Feitosa IM, Horovitz DD, Cavalcanti DP, Pessoa A, et al. Possible Association Between Zika Virus Infection and Microcephaly-Brazil, 2015. MMWR Morb Mortal Wkly Rep. 2016;65(3):59-62. DOI: https://dx.doi.org/10.15585/mmwr.mm6503e2

24. European Centre for Disease Prevention and Control (ECDPC). Microcephaly in Brazil potentially linked to the Zika virus epidemic. [cited 2016 Jan 26] Available from: http://ecdc.europa.eu/en/publications/ Publications/zika-microcephaly-Brazil-rapid-risk-assessment-Nov-2015.pdf.

25. Centers for Disease Control and Prevention (CDC). Concludes Zika causes Microcephaly and Other Birth Defects. [cited 2018 Jan 31] Available from: http://www.cdc.gov/media/releases/2016/s0413-zikamicrocephaly.html

26. World Health Organization (WHO). Zika Virus, microcephaly, and Guillain Barré Syndrome. World Health Organization, 2016.

27. Santos JLG, Lima MVM, Leitão FNC, Costa VDE, Macedo Jr H, Muniz PT. Zika virus and measures of legal interventions in public health. J Hum Growth Dev. 2016;26(3):393-7. DOI: http://dx.doi.org/10.7322/jhgd.122919

28. Mlakar J, Korva M, Tul N, Popović M, Poljšak-Prijatelj M, Mraz J, et al. Zika virus associated with microcephaly. N Engl J Med. 2016;374(10):951-8. DOI: http://dx.doi.org/10.1056/NEJMoa1600651

29. Miranda-Filho DB, Martelli CM, Ximenes RA, Araújo TV, Rocha MA, Ramos RC, et al. Initial description of the presumed congenital Zika Syndrome. Am J Public Health. 2016;106(4):598-600. DOI: http://dx.doi.org/10.2105/AJPH.2016.303115

30. Rasmussen SA, Jamieson DJ, Honein MA, Petersen LR. Zika Virus and birth defects-reviewing the evidence for causality. N Engl J Med. 2016;374(20):1981-7. DOI: http://dx.doi.org/10.1056/NEJMsr1604338

31. Ventura CV, Maia M, Dias N, Ventura LO, Belfort Jr R. Zika: neurological and ocular findings in infant without microcephaly. Lancet. 2016; 387(10037):2502. DOI: https://dx.doi.org/10.1016/S0140-6736(16)30776-0

32. França GVA, Schuler-Faccini L, Oliveira WK, Henriques CM, Carmo EH, Pedi VD, et al. Congenital Zika virus syndrome in Brazil: a case series of the first 1501 livebirths with complete investigation. Lancet. 2016;388(10047):891-7. DOI: https://dx.doi.org/10.1016/S0140-6736(16)30902-3

33. van der Linden V, Pessoa A, Dobyns W, Barkovich AJ, Linden Júnior H, Rolim Filho EL, et al. Description of 13 Infants Born During October 2015-January 2016 With Congenital Zika Virus 
Infection Without Microcephaly at Birth- Brazil. MMWR Morb Mortal Wkly Rep. 2016;65(47):1343-8. DOI: http://dx.doi.org/10.15585/mmwr.mm6547e2

34. Zin AA, Tsui I, Rossetto J, Vasconcelos Z, Adachi K, Valderramos S, et al. Screening Criteria for Ophthalmic Manifestations of Congenital Zika Virus Infection. JAMA Pediatr. 2017;171(9):847-54. DOI: http://dx.doi.org/10.1001/jamapediatrics.2017.1474

35. Levine D, Jani JC, Castro-Aragon I, Cannie M. How Does imaging of congenital Zika compare with imaging of other TORCH infections? Radiology. 2017;285(3):744-61.

DOI: http://dx.doi.org/10.1148/radiol.2017171238

36. Moore CA, Staples JE, Dobyns WB, Pessoa A, Ventura CV, Fonseca EB, et al. Characterizing the Pattern of Anomalies in Congenital Zika Syndrome for Pediatric Clinicians. JAMA Pediatr. 2017;171(3):288-95. DOI: http://dx.doi.org/10.1001/jamapediatrics.2016.3982

37. Ventura CV, Maia M, Bravo-Filho V, Góis AL, Belfort Jr R. Zika virus in Brazil and macular atrophy in a child with microcephaly. Lancet. 2016;387(10015):228. DOI: https://doi.org/10.1016/S0140-6736(16)00006-4

38. Freitas BP, Dias JRO, Prazeres J, Sacramento GA, Ko Al, Maia M, et al. Ocular Findings in Infants With Microcephaly Associated With Presumed Zika Virus Congenital Infection in Salvador, Brazil. JAMA Ophthalmol. 2016. DOI: https://doi.org/10.1001/jamaophthalmol.2016.0267

39. Ventura CV, Maia M, Ventura BV, van der Linden V, Araújo EB, Ramos RC, et al. Ophthalmological findings in infants with microcephaly and presumable intra-uterus Zika virus infection. Arq Bras Oftalmol. 2016;79(1):1-3. DOI: http://dx.doi.org/10.5935/0004-2749.20160002

40. Yepez JB, Murati FA, Pettito M, Peñaranda CF, Yepez J, Maestre G, et al. Ophthalmic manifestations of congenital Zika Syndrome in Colombia and Venezuela. JAMA Ophthalmol. 2017;135(5):440-5. DOI: http://dx.doi.org/10.1001/jamaophthalmol.2017.0561

41. Jin HD, Demmler-Harrison GJ, Coats DK, Paysse EA, Bhatt A, Edmond JC, et al. Long-term visual and ocular sequelae in patients with congenital cytomegalovirus infection. Pediatr Infect Dis J. 2017;36(9):877-82. DOI: http://dx.doi.org/10.1097/INF.0000000000001599

42. Maenz M, Schlüter D, Liesenfeld O, Schares G, Gross U, Pleyer U. Ocular toxoplasmosis past, present and new aspects of an old disease. Prog Retin Eye Res. 2014;39:77-106. DOI: http://dx.doi.org/10.1016/j.preteyeres.2013.12.005

43. Linden VV, Linden Junior HV, Leal MC, Rolim Filho EL, Linden AV, Aragão MFVV, et al. Discordant clinical outcomes of congenital Zika virus infection in twin pregnancies. Arq Neuropsiquiatr. 2017;75(6):381-6. DOI: http://dx.doi.org/10.1590/0004-282X20170066

44. Alves LV, Cruz DDCS, van der Linden AMC, Falbo AR, Mello MJG, Paredes CE, et al. Epileptic seizures in children with congenital Zika virus Syndrome. Rev Bras Saude Mater Infant. 2016;16(Suppl 1):S2731. DOI: http://dx.doi.org/10.1590/1806-9304201600s100003

45. Jucá E, Pessoa A, Ribeiro E, Menezes R, Kerbage S, Lopes T, et al. Hydrocephalus associated to congenital Zika Syndrome: does shunting improve clinical features? Childs Nerv Syst. 2018;34(1):101-6. DOI: http://dx.doi.org/10.1007/s00381-017-3636-2

46. Oliveira-Szejnfeld PS, Levine D, Melo AS, Amorim MM, Batista AG, Chimelli L, et al. Congenital brain abnormalities and Zika Virus: what the radiologist can expect to see prenatally and postnatally. Radiology. 2016;281(1):203-18. DOI: https://dx.doi.org/10.1148/radiol.2016161584

47. Prata ARS, Pedroso D, Menezes G, Drezett J, Torres JHR, Bomfim JRA, et al. Juridical perspectives of interruption of pregnancy with zika virus infection regarding medical, emotional and social consequences. J Hum Growth Dev. 2018;28(1):77-81. DOI: https://doi.org/10.7322/jhgd.143875

48. Machado LDS, Ramos JLS, Machado MFAS, Antão JYFL, Santos SB, Bezerra IMP, et al. Participatory process of health promotion at school. J Hum Growth Dev. 2015;25(3):357-63. DOI: http://dx.doi.org/10.7322/jhgd.106014

49. Bezerra HMC, Machado MFAS, Antão JYFL, Mello CMB, Abreu LC, Garcia TTB, et al. Community health agent and the interface with the educational actions. Int Arch Med. 2015;8(153):1-10. DOI: http://dx.doi.org/10.3823/1752

50. Bezerra IMP, Sorpreso ICE. Concepts and movements in health promotion to guide educational practices. J Hum Growth Dev. 2016;26:(1):11-20. DOI: https://doi.org/10.7322/jhgd.113709

51. Schram PCF. Zika virus and public health. J Hum Growth Dev. 2016;26(1): 7-8. DOI: http://dx.doi.org/10.7322/jhgd.114415

52. Caires-Junior LC, Goulart E, Melo US, Araujo BHS, Alvizi L, Soares-Schanoski A, et al. Discordant congenital Zyka syndrome twins show differential in vitro viral susceptibility of neural progenitor cells. 
Nature Communications. 2018;475(9):1-11. DOI: http://dx.doi.org/10.1038/s41467-017-02790-9

53. Brasil. Ministério da Saúde. Secretaria de Vigilância em Saúde. Protocolo de vigilância e resposta à ocorrência de microcefalia e/ou alterações do sistema nervoso central (SNC). Brasília: Ministério da Saúde, 2016.

\section{Resumo}

Introdução: A infecção pelo Zika vírus (VZIK) foi emergência em saúde pública de interesse nacional brasileiro até maio de 2017, devido ao súbito aumento de nascidos com microcefalia e outras alterações neurológicas durante a epidemia iniciada no Brasil em novembro de 2015. As manifestações da infecção intrauterina pelo VZIK são mais graves quando ocorrem no primeiro e segundo trimestres de gestação, principalmente no primeiro trimestre. Nesta situação, o diagnóstico precoce dos problemas visuais é imprescindível para que os pacientes apresentem avanços nos campos neurológicos e até motores, sendo que há complicações como erros refrativos (miopia, astigmatismo e hipermetropia), estrabismo e hipoacomodação. A ausência de microcefalia em lactentes expostos ao Zika vírus não é indicativo de alterações ofatalmológicas, sendo imprescindível ap médico oftalmologista realizar as investigações spertinentes ao caso clínico. Toda e qualquer lesão ocular e em seus anexos são graves. Quanto mais precoce for o diagnóstico, mais cedo a criança pode ser submetida a uma intervenção para habilitação da visão.

Objetivo: Analisar padrão atípico de gemelares com Zika congênita presumida e sem microcefalia.

Método: Trata-se de um relato de caso, desenvolvido na cidade de Serra Talhada, interior do estado de Pernambuco, Nordeste Brasileiro.

Relato: Caso de gemelares cuja mãe foi exposta ao Zika vírus no segundo trimestre de gestação (décima primeira semana). As crianças nasceram prematuras e sem microcefalia. Um dos gemelares apresentou hidrocefalia com necessidade de intervenção cirúrgica. A mesma criança foi levada para exame oftalmológico por possuir estrabismo convergente e foi encontrado nervo óptico hipocorado e cicatriz coriorretiniana em região macular em ambos os olhos semelhantes às lesões descritas pelo Zika vírus. Quadro similar, mas com menor comprometimento visual foi identificado no segundo gemelar. A tomografia de crânio demonstrou focos de calcificação nos hemisférios cerebrais bilateralmente.

Conclusão: Houve presença de desvio convergente e nistagmo às lateroversões. Na fundoscopia, o nervo óptico apresentou-se hipocorado e com lesão coriorretiniana cicatricial com bordos bem delimitados em área macular de ambos os olhos.

Palavras-chave: gravidez, Zika Vírus, oftalmologia, transtornos de visão. 